\title{
Fifty Years of Indonesian Development: "One Nation," Under Capitalism...
}

\author{
by \\ Brian McCormack \\ Department of Political Science \\ Arizona State University \\ Tempe, Arizona 85287-2001 USA \\ e-mail: mccormack@asu.edu
}

Cite: McCormack, Brian. (1999). "Fifty Years of Indonesian Development: 'One Nation,' Under Capitalism..." Joumal of World-Systems Research http://jwsr.ucr.edu/ 5: 48-73.

(C) 1999 Brian McCormack.

[Page 48]

Journal of World-Systems Research

In Indonesia much uncertainty remains in the wake of the dramatic changes that unfolded in the latter half of the 1990's. By the end of the 20th century, the Indonesian economy was in ruins. The concept of democracy remained contested. The transportation and communication system that once at least minimally linked the diverse and at times disparate areas and peoples of the Indonesian archipelago into an Andersonian imagined national community collapsed, making more likely movements for regional autonomy, in turn, making the status of an Indonesian nation itself uncertain. One thing that is certain, however, is that Soeharto, the "Father of Development," is history. As political and economic policy makers in Indonesia, the United States, and around the world, and more importantly, Indonesia's men, women, and children pick up the pieces, it is our responsibility to look back and consider the past fifty years.

Indonesian development has been marked by a struggle between two opposing forces: one that is commensurate with self-reliance predicated upon an ideology of nationalism, and another that positions Indonesia within global capitalism. The issue that I shall address here is the degree to which the strategies of development were determined by a culture of capitalism or, alternatively, by a culture of nationalism. In fact, both appear in the development strategies under Sukarno and Socharto. However, the manner in which the idea of the nation was deployed in attempts to effect development differed significantly. This difference helps explain the difference in the nature of the failures of both strategies--failures which have brought Indonesians to the political and economic crisis in which they now find themselves.

In the world-system, "culture" might be seen in one of two ways. In his analysis of Dutch hegemony in the mid-17th century, Wallerstein argues, "Cultures are precisely arenas 
where resistance to hegemony occurs, where appeals are made to the historical values of established 'civilizations' against the temporary superiorities of the market." (1980:65). ${ }^{1}$ On the other hand, there also exists a "bourgeois culture" and nascent bourgeois and proletarian "praxis" in the struggle in the core for hegemony in the mid-18th century (Wallerstein 1980). In my work here, I trace the development of the cultures of capitalism and nationalism as they appear in the development strategies in Indonesia. In effect, the world-system does not bear a unified architectural form. Instead, to the extent that one might speak of a capitalist world-system, it must be thought of as remaining in formation, still subject to the challenges of other "systems," notably, as the case of Indonesia demonstrates, nationalism, as it is played out in specific historical and cultural experiences. ${ }^{2}$

Under Sukarno, Indonesian development initially (and briefly) followed the designs of a Western-led understanding of development. By the late 1950's, however, Sukarno distanced himself from the capitalist world-system and turned to development strategies entrenched within an ideology of nationalism. Under Socharto, Indonesia's rocket-paced aggregate levels of development--levels whose measurement of "success" was greatly flawed--resulted from increasing integration into the world-system; but economic integration relies upon another kind of integration. I intend to demonstrate that economic integration profits from a "cultural" foundation of capitalism.

[Page 49]

Journal of World-Systems Research

Gramsci's notion of ideology offers a view of capitalism as more than simply materialist "superstructure" and is therefore useful in my discussion of the culture of capitalist ideology in Indonesia. Laclau and Mouffe (1985) explain that, for Gramsci, "Ideology is not identified with a 'system of ideas' or with the 'false consciousness' of social agents; it is instead an organic and relational whole, embodied in institutions and apparatuses, which welds together a historical bloc around a number of basic articulatory principles. . For Gramsci, political subjects are not--strictly speaking--classes, but complex 'collective wills"' (p. 67). In Indonesia under Socharto, the discourse of development retained a rhetoric of nationalism, while, at the same time, Indonesians were accepting the terms of trade, so to speak, of capitalism--terms that were part of a culture of capitalist ideology, embodied in the policies and practices of the institutions of capitalism in the worldsystem, and diffused in Indonesian society, as it became increasingly part of a complex of "collective wills."

I organize this essay as follows: 1) theoretical framework, 2) development under Sukarno, 3) development under Socharto, and 4) an analysis of Indonesia's attempt to "ascend" in the world-system, including an assessment of the claims to success in that attempt. In effect, the dualistic demands of capitalism and nationalism resulted in a hybrid of development strategies in which one or the other cultural orientation predominated. The contradictions inherent in Indonesian development are understandable 
according to the particular history of Indonesia as a postcolonial state--as a site of the political, economic, and ideological struggle for dominance between Indonesian forces of nationalism and global forces of capitalism--a struggle that is likely to continue into the next century.

\section{Theroretical Framework}

According to World-System Theory (Wallerstein 1974; 1980; 1984; 1988; Wilkinson 1996), a mutually reinforcing system of nation-states and a market system of capitalism emerged in Europe between 1450 and 1620. The system, through processes of broadening and deepening, has developed over time and now encompasses virtually all areas of the world. It is divided, in an international division of labor, into zones of economic activity in which the core states, through unequal exchange, exploit peripheral areas and states. The underlying principle upon which exploitation is based is an effort by the capitalist class in the world-system to profit from this relationship, by deriving surplus capital and expanding markets. Between the zones of core and periphery is the semi-periphery. A similar relationship exists between core and semi-periphery. In this case, capital derived by the core from the semi-periphery comes from commodities that require more advanced technologies--industrial rather than agricultural. First incorporation and then integration occurs. The semi-peripheral states work to ascend towards the core by engaging in core like activities (Chase-Dunn 1990; 1981). The core itself attempts to maintain its position relative to the other zones. The process involves a series of economic cycles, or Kondratieff waves in which there are alternating periods of global economic growth and of economic stagnation/contraction/hegemonic decline (Goldstein 1988; Avery and Rapkin 1982). Throughout the period under investigation in this work the system was undergoing contraction and the hegemonic decline of the United States.

[Page 50]

Journal of World-Systems Research

This basic theoretical framework has been supplemented (Wallerstein, Arrighi, and Hopkins 1986) with the notion of a transformed historical ground, which has three dimensions. First, there has been both a widening and deepening of stateness. Additionally, the activities of a number of regional international organizations (such as OECD, OPEC, ASEAN, COMECON, NATO, OAU etc.) further increase the "relational networks" ${ }^{4}$ between states as well as the tasks of the individual states themselves. Second, Wallerstein locates "organizing centers" of the "core of socialization of production" (p. 202), otherwise known as transnational (multinational) corporations. Their "reconstruction of the world-scale division and integration of labor processes fundamentally alters the historical possibilities of what still are referred to, and not yet even nostalgically, as 'national economies"' (p. 203). The third dimension of a "transformed historical ground" is what Wallerstein sees as a replacement mechanism of colonial empires. "Massive centralizations of capital. . .has as its agencies quite small ad hoc steering committees of consortia, each composed of several hundred banks" (p.204). 
These include such international agencies as the World Bank and the In ternational Monetary Fund (IMF). Wallerstein recognizes the difficulty this "transformed historical ground" creates for the "managers of the status quo," (p. 206) but he also sees that "it creates dilemmas for the antisystemic movements almost as grave" (p. 206). These dimensions must be addressed in the case of Indonesia, a state that entered the worldsystem as a state only after the departure of Dutch colonialists and the Japanese following World War II.

This, then, is the basic global theoretical framework of World-System Theory. As I see it, the case of Indonesia requires further theoretical consideration to account for the course of its development strategies. Friedman (1989) posits a broad model of the uses of "culture" which can be useful in explaining Indonesia's development strategies. On one hand, Indonesian development, at times, follows a pattern commensurate with a capitalist orientation. On the other hand, "nationalism" might be seen as an effective ideological tool for nation-building. According to Friedman:

In periods of expansion. . . there is a tendency for local self-reproductive systems to. . .become integrated into the larger colonial and international systems ... Ultimately there is a strong tendency toward assimilation, toward the identification. . . with the model of the center, with a modernism that appears associated with success. . . This process is reversed in times of contraction. As modernism collapses in the center, there is an exponential increase in cultural identity both at home and abroad. At home there is a search for that which has been lost, and in the periphery for a cultural or even national autonomy previously repressed by the center. Cultural identity, from ethnicity to a "way of life" flourishes at the expense of the system. (pp. 66-68)

Prior to World War II, the world-system was undergoing expansion. Dutch colonialism was, in fact, commensurate with integration into the "the larger colonial and international systems. . . [with] a strong tendency toward assimilation, toward the identification. . .with the model of the center, with a modernism that appears associated with success." Since World War II, the world-system underwent a period of contraction. As a result, one would expect an increase in a search for an Indonesian cultural identity. This was, in fact, the case with Indonesia. The Indonesian search for identity during both the Sukarno and Soeharto periods was reflected in the ongoing struggle between forces of nationalism and forces of capitalism. How this played out, however, differed under Sukarno and Soeharto. Whereas the Sukarno regime searched for an Indonesian identity that continued with the notion of an Indonesian nation opposed to colonialism and global capitalism, the Soeharto regime sought an Indonesian national identity that would contribute to the system of global capitalism. The language of nationalism appeared in both development strategies but with different purposes. 
Heryanto (1988) examines the changing meaning of "development" in Indonesia from the beginning of the nationalist movement through the Suharto years. Heryanto's linguistic analysis can be seen as consistent with World-System Theory in the following way. Besides the unequal political and econo mic relationships that exist between core and periphery, there is also an unequal linguistic relationship. "Weaker states are required to use the language--meaning that they must follow the logic and the methods of understanding which are part of this language--that belongs to the states which are stronger" (p. 13). "Development" (in Indonesian, "pembangunan") was initially connected with the early ideas of nationalism, primarily during the late 1930 's, the period of the "Cultural Polemics." "The meaning of pembangunan and membangukan [the verb form of the word] at that time can perhaps best be understood as equivalent to 'building' in 'nation-building' and 'character-building' which became popular expressions in subsequent periods" (p. 9).

The argument as it relates to my own can be summarized in Heryanto's observation of the effect of "development" in the period under investigation here. During Sukarno's reign, "development," understood as "nation-building," was related to "the older sense of 'membangun numah' ('building a house')" (p. 22). It follows that "Pembangunan nasional (national development) has shown its most impressive achievements in the creation of a number of physical buildings" (p. 22). These include monuments, government buildings, sports complexes, and so on. On the other hand, under Soeharto, "The Pembangunan led by the New Order focused primarily on the creation and improvement of the infrastructure for industrialization" (pp. 22-23). "Building" under Sukarno was primarily a symbolic gesture meant to consolidate a nation-state against the external forces of the world-system. "Building" under Socharto meant economic development in line with the external forces of the world-system.

In general, as Heryanto explains, Indonesia has been in the position of having to regard "development" using "a number of Indonesianized, Javanized, or similarly ethnicized, 'biases' or 'dialects,' which are perhaps unintentional, resulting from [an] effort to talk about Development with a 'grammar' that comes from the West" (Heryanto 1988: 14-15). The Indonesian language, as a key element of culture, which became the lingua franca (literally the language of commerce) in Indonesia, depended upon the degree to which Indonesia was associated with the capitalist world-system. ${ }^{5}$ As such, the concept of "development" in Indonesia, in both periods, was constructed by "modernist" notions of "development." However, whereas the "Great Leader of the Revolution" (Sukarno) used development as part of a national resistance to the system, the "Father of Development" (Socharto) used development to integrate Indonesia into the system.

In principle, the rhetoric of nationalism remained under Socharto as part of the struggle to locate an Indonesian identity, but in practice this search for identity proceeded within a dominating culture of capitalist economic development. In other words, under Soeharto, there continued to be a search for an Indonesian identity in the struggle between development strategies, but this search for identity became part of an effort to seek 
identification with the global capitalist system. I turn now to an examination of the development strategies under Sukarno and Socharto.

[Page 52]

Journal of World-Systems Research

\section{Development Under Sukarno}

The colonial history of the Indonesian archipelago is a series of periods of domination and resistance. ${ }^{6}$ Independence in 1949 was preceded by Portuguese and then Dutch colonialism, until 1942, when Japan occupied the region. Between 1945 and 1949, the Dutch again ruled Indonesia. Sukarno became the "Great Leader of the Revolution" upon independence. The path of "development" under Sukarno is complex and tortuous, and can only be given brief attention here. (Pitt 1991; Arndt 1984; Feith and Castles 1970; Devan 1987; Drake 1989; Glassburner 1971; Papanek 1980; Wilson 1989.)

The period between 1949 and 1959 eventuated in a reaction to global capitalism, which Indonesians associated generally with imperialism and in particular with the memory of Dutch colonialism. Initially, Indonesian policy makers responded to economic domination by attempting to copy multi-party democracy, and by attempting, to some degree, to play by the rules of global capitalism. Three attempts to liberalize the economy, in 1950-51, 1955, and 1957 (which were, in effect, attempts to integrate the Indonesian economy into the world economy) all failed because of an inability to coordinate political wills. The impasse between gestures towards liberalization and continuing efforts to build an Indonesian nation was finally settled in 1958-1959 by which time Sukarno had supplemented the basic form of his "Guided Democracy" by instituting "Guided Economy." ${ }^{7}$ Even at this point the development plans generated under the rubric of "Guided Economy" were to be financed through reliance on foreign aid, particularly from the United States. However, throughout the 1950's, there is evidence of Indonesia's reticence to accept America's terms of assistance. Essentially, assistance from the United States was an attempt to define Indonesia's development strategies, a definition that the Indonesians were generally not willing to accept.

Moon (1998) describes a conflict of development strategies between the United States and Indonesia over agricultural production during the 1950's that illustrates the incommensurability between them, and meant the eventual move away from reliance upon the United States by the Sukarno regime. Whereas Indonesia hoped to increase rice productivity through increased use of mechanization, the United States had in mind a development of Indonesian agriculture through technical training and education. As Moon notes:

Howard Jones, ambassador to Indonesia. . . called this emphasis on training "the struggle for the Indonesian mind." By training Indonesians in American best practice for agriculture and extension, the [International Cooperation Administration] hoped to create 
a set of institutions that would foster the "proper" sort of economic development and thus to pre-empt any slide toward communism. (p. 203) $\stackrel{8}{\underline{8}}$

In general, the Indonesians were more interested in procurement of machinery than in technical training. For the United States, this was one instance of a global ideological battle between communism and capitalism. Moon continues: "As American officials discovered, Indonesian actors, even those with U.S. training, did not necessarily use their knowledge in predictably American ways, nor wholly adopt American interpretations of the goals of development. The struggle to control development was at the same time a struggle to define it" (p. 211).

[Page 53]

Journal of World-Systems Research

The Sukarno regime, suspicious of the motives of aid from the West, turned away from the West and toward socialist states, particularly the People's Republic of China (Simon 1969), and the Soviet Union and the Eastern Bloc for development assistance. Sukarno made clear his disdain for Western ideas about Indonesian development. Near the end of his rule, he referred to the ideas of "bald-headed professors, from Oxford, from Cornell University or elsewhere" ${ }^{2}$ as "inapplicable to the peculiar circumstances of Indonesia" (Tan 1967:33). His primary concern, perhaps even paranoia, was with the loss of control that Western development aid might mean to his rule and his interpretation of the idea of an Indonesian nation. By the latter part of his career, his rhetoric highlighted his claims to nationalism:

We do not want help from anyone at all, and we are not going to beg for it. We are a Great Nation; we are not an insignificant nation. We are not going to beg, not going to ask for this and ask for that, especially if aid has this condition and that tie tacked onto it! Better to eat poverty rations of cassava and be independent than eat beefsteak and be enslaved! $\stackrel{10}{ }$

Of course, the Indonesian poor were lucky to get poverty rations, as starvation was a common effect of Sukarno's misguided "Guided Economy."

The Sukarno regime rejected Western foreign assistance, and withdrew from the worldeconomy, by separating itself from the United Nations and its affiliated organizations, the IMF and the World Bank. This move was bound to fail, primarily because of the existing catastrophic condition of the economy. "Socialism" for Sukarno was, as has so often been the case, mistranslated into authoritarianism geared toward creating a unified nation-state. Chase-Dunn's (1990) observation helps explain the failure of "Indonesian Socialism":

Socialist movements which take place in the periphery are soon beset by powerful external forces which either overthrow them or force them to abandon most of their socialist program. Anti-systemic movements in the periphery are most usually antiimperialist class alliances which succeed in establishing at least the trappings of national 
sovereignty, but not socialism. The low level of the development of the productive forces also makes it harder to establish socialist forms of accumulation (p.26).

It is significant not only that during the Sukarno era "development" failed miserably, but also that the meaning of "development" was connected more with nation-building, and less with economic growth.

The change in emphasis in the meaning of "development," that is, from development as nation-building to the economic development of the nation, serves as a bridge between the Sukarno and Socharto regimes. In effect, a culture of nationalism gave way to a culture of capitalism, and the resulting change in emphasis in development strategies reflected this cultural shift. What is puzzling is that during the Soeharto period, Indonesian officials did not abandon nationalism. "Development" retained the trappings of nationalistic ideology. However, whereas Sukarno's Guided Democracy and Guided Economy framed development in a culture of nationalism, Soeharto's references to nationalism were themselves framed within a culture of global capitalism, and were used in the service of the capitalist world-system.

[Page 54]

Journal of World-Systems Research

Indonesian Development Under Soeharto

Liddle (1991) argues that Soeharto was the primary deciding force in Indonesian development during the period of the New Order, and that "the persuasiveness of the theories of his economists has interfaced with political culture and ideology and with the patrimonial base of the political system to produce an enduring formula that combines liberal economics with illiberal, but not entirely unpopular, politics" (p.423). Notwithstanding the lack of "endurance" of this formula, Liddle's argument is convincing to the extent that these contending forces might go unquestioned. 11 A more fundamental issue is the underlying cultural basis of the "theories of his economists," created out of the modern world-system. The choices that New Order Indonesia made were necessarily driven by the forces that constituted that system. On the one hand, a decision to move toward liberalization was prompted by economic necessity, riding on the heels of Sukarno's economic catastrophe. On the other hand, a decision to move in a "nationalist" direction, that is, "illiberal politics," might be construed as part of a continuing reaction to the capitalist global economy. However, despite a few pauses in liberalization policies, the general tendency in the overall Indonesian development policy under Soeha rto was toward integration into the world-system. One indication of this was the continuance of state-led economic policies that served the interests of the center (in Java and particularly in Jakarta)--a center which was content to trade and do business with a globalizing market, but which persisted in denying the "advantages" of liberalization to the business interests and sectors of the economy that existed on the outer islands. ${ }^{12}$ In the end, the success of Soeharto's policy was measured in relation to the system. 
The following analysis of development in Indonesia under Soeharto will take into account the basic elements of World-System Theory, supplemented by the three dimensions of Wallerstein's "transformed historical ground." The overwhelming power of this transformed historical ground incorporated the Indonesian economy and made possible the acceptance and reliance upon the theories of Indonesia's Western -educated economists in development strategies that were based upon the culture of global capitalism.

Sukarno's "Guided Economy" was, in the end, a dissociation away from the world market. The general trend under Soeharto was towards integration into the world market. The question that I want to ask now is whether development under Soeharto retained the language of nationalism, and, if it did, whether that language was primarily a way to serve the interests of capitalism.

The shift towards world market integration, beginning in 1966, was as dramatic as the previous move towards dissociation.

The period 1966-71 saw sweeping changes. . . There was a dramatic shift from the direct control of almost all aspects of the modern economy toward heavy reliance on market signals and price incentives. This period saw the end of most direct allocations of foreign exchange, the elimination of most price controls, an opening to foreign investment, and the acceptance of the private sector as the primary source of economic growth. The important distinction between this liberalization attempt and its numerous predecessors is that it encompassed not merely liberalizing acts but also the destruction of important antiliberal forces -- replacing a strongly antiliberal state ideology with one that was nominally liberal, virtually eliminating powerful antiliberal political parties, and dismantling some important institutions of state control (Pitt 1991:78).

[Page 55]

Journal of World-Systems Research

Development was also institutionalized in a series of "Five Year Development Plans," known as "Repelita." These plans are important for a number of reasons. First, the bureaucrats responsible for writing and promoting the policies contained within them were a group of Western-educated economists, often refe rred to as the "Berkeley Mafia." Second, the genesis and formulation of these development plans were carried out under the influence of the IMF. Third, the changing emphases in Indonesian economic development policy can be traced in them. Fourth, the discourse of nationalism is a feature of each of the plans. Finally, the importance given to the concept of development in Indonesia during this period is symbolized in the relationship between these Development Plans and the Development Cabinets, as they have been called since 1968 .

Development in Indonesia under Soeharto proceeded within the world-system both in terms of the cultural basis required for integration into the system, and in terms of the 
economic and political structure and dynamics of the system. During the New Order under Socharto there is evidence of an increasing capitalist orientation both within the government, and in society in general. To begin, what has often been called the "Berkeley Mafia" was a group of economic bureaucrats in the Development Cabinets. ${ }^{13}$ Perhaps the central figure among the "capitalist bureaucrats" was Widjojo Nitisastro, who became Minister of State for National Development in 1968, and was named Minister of State for Economic, Financial and Industrial Affairs in 1973. In 1979, he also held the position of Chairman of the National Planning Board (BAPPENAS). In 1983, Johannes Sumarlin assumed the roles of Minister of State for National Development Planning, and of Chairman of BAPPENAS. He had previously been Minister of State for Administrative Reforms from 1968. Ali Wardhana was Minister of Finance from 1968-1982. Then, from 1983 to 1987, he was Minister Co-ordinator for the Economy, Finance, Industry and Development Supervision. Emil Salim began in 1968 as Minister of State for the Reorganization of the State Apparatus and Minister of Communication from 1972 to 1979. Salim also became Minster of State for Supervision of Development and the Environment in 1981, a title which changed in 1984 to Minister of State for Population and the Environment. All of these men received Ph.D.'s in economics from the University of California at Berkeley, hence, the "Berkeley Mafia."

There were also a number of other key officials who were educated elsewhere in the West. Among these is Radius Prawiro, a graduate of the Nederlandsche Economische Hogeschool, and a Doctor of Economics at the University of Indonesia. Prawiro began as Minister of Trade in 1973 (changed to Minister of Trade and Cooperatives in 1979), and was Minister of Finance until he was replaced by Sumarlin. Rachmat Saleh, also a Ph.D. in Economics from the University of Indonesia, took Prawiro's position as Minister of Trade in 1983. Bucharaddin Jusuf (Ben) Habibie (Soeharto's successor), who graduated with a doctorate from the Technical University in Aachen, West Germany, was first Minister of State for Research and Technology in 1973, and also became Chairman of the Board for the Study and Application of Technology 1984. In 1976, Soebroto, a Ph.D. from Harvard, became Minister of Manpower, Transmigration and Cooperatives. Arifin Siregar was Minister of Trade beginning in 1989, and served as the Governor of the Bank of Indonesia in 1987 and 1988. His Ph.D. is from the University of Muenster.

[Page 56]

Journal of World-Systems Research

Besides these central figures in the Indonesian government, there was further evidence of a general movement in Indonesia towards a cultural orientation commensurate with Western capitalism. The following are a few examples of influential individuals who received Western training. 14

Teuku Umar Ali (Ph.D., Cornell University) Coordinator of Economic and Social Research and Assistant Dean, Faculty of Economics, University of Indonesia.Alwi Muhammad Dahlan (Ph.D., University of Illinois) Assistant to Minister of State for Development and the Environment, Lecturer of Faculties of Social Politics, Hasanuddin 
University and University of Indonesia.Dono Iksandear Djojosubroto (Ph.D., University of Illinois) Directorate-General of Foreign Monetary, Finance Department.Hariri Hady (Ph.D., Berkeley) Lecturer at Faculty of Economics, University of Indonesia, Head of Regional Social Economic Bureau, BAPPENAS.Daoed Joesoef (Ph.D., University de Paris I Patheon-Sorbonne) Minister of Education and Culture, Chairman of the Department of General Economics, University of Indonesia.Mubyarto (Ph.D., Iowa State University) Lecturer, Faculty of Economics, Gadjah Mada University, Yogyakarta.Anwar Nasution (Ph.D., Tufts University) Member of Macroeconomic Study Group, The World Bank, Lecturer in Economics, University of Indonesia.Halim Shahab (Ph.D., Berkeley and University of Indonesia) President of PT Jakarta Industrial Estate Pulogadung, Member of Indonesian Delegation to the World Bank for credit negotiations. Juwono Sudarsono (Ph.D., Berkeley) Chairman of the Department of International Relations, University of Indonesia.Zainul Yasni (Ph.D., Vanderbilt University) Head of Development Center for the marketing of agricultural commodities/National Export Development Agency, Trade Department.Buchari Zainun (Ph.D., Indiana University) Director of Staff School for Civil Servants.

A glance at the brief resumes of these people suggests a diversity of educational backgrounds (though all Western educated). What is more interesting is that many of the people who held (and in some cases still hold) influential government positions were also professors at leading universities in Indonesia. This suggests that a capitalist culture likely became diffused throughout the economic and political centers, through education, to young scholars who are likely to represent the next generation of policy makers and bureaucrats. The diffusion of this culture supported the creation of the sort of Gramscian "political wills" that were commensurate with the formation of a global hegemonic bloc of capitalism.

Again, these bureaucrats and scholars were the people responsible for policy formulation (writing development plans) and policy implementation (carrying out development plans). Their capitalist orientation derived in part from their educational background. However, there was another, more direct influence on these people. Several of the people in the list above were involved in World Bank discussions and education programs. Needless to say, the World Bank and the IMF are in the business of the capitalist development of places like Indonesia. Very simply, as far as the core is concerned, a semi-peripheral Indonesia would be preferable to a peripheral Indonesia because of its potential as a market for core commodities, and as a source of industrial labor. This is the bottom line as to why the IMF was (and is still) willing to inject the Indonesian economy with its billions.

[Page 57]

Journal of World-Systems Research 
One of the first measures of the New Order regime was to apply for readmission to the IMF, the World Bank, and the United Nations. Missions from the IMF and the World Bank visited Indonesia in mid-1966 to assist in formulating economic policy. They were instrumental in arranging a meeting of representatives of the non-Communist creditor nations at a conference in Tokyo in September 1966 to discuss proposals for a moratorium on Indonesia's debt commitments (Pitt 1991:115).

Indonesia has since relied on the IMF and the World Bank to oversee and help finance the programs recommended in the development plans. After decades of involvement wi th these organizations, of having these centers of global capital influence the course of Indonesian development, of having been acculturated into a system that recommends a capitalist orientation of its members, Indonesians, and importantly, the key figures in the Indonesian government, became increasingly willing to seek integration into the worldsystem. Indonesia's reliance on the core, in a period of a "transformed historical ground," has also increased in the form of ongoing consultation and negotiation with the World Bank and the IMF. In fact, Indonesia's reliance on the IMF for its very economic existence is a stark contrast with the random token assistance of the 1950's and early 1960 's. I shall now examine more closely the development plans (Repelita), and the actual patterns (and results) of "development," which further indicate the capitalist orientation of Indonesian development under Soeharto.

A number of elements are common to all of the five-year plans. Each begins with an introduction of the "targets of development," and a chapter concerning the financing of the plan. Consideration is given to each of the following, in one form or another: agriculture, irrigation, food, industry, mining and energy, manpower, transmigration, housing, science and technology, health, population and family planning, regional development, the law and justice, communication and tourism, national defense and security, information, the press, and the government apparatus/administration of the plan. Emphasis changed through the course of the plans. For example, as the economy expanded, manpower became important due to an increasing urban workforce. Repelita I does not consider technology, whereas research and development became important in the later plans. Repelita $\mathrm{V}$ is notable for its consideration of the "role of women," though in terms almost solely of "family welfare" and health issues.

What is most notable, at least in terms of a rhetoric of nationalism cultural continuity with the Sukarno period, is the section in Repelita V on "National Culture and Belief in the One and Only God." Notice the wording of the following key passages:

The national culture which is founded on Pancasila is directed towards giving an insight into and meaning to national development in all aspects of life so that in this way national development is development which is culture oriented. . .

Efforts towards national assimilation need to be continued in all sectors of life within the framework of strengthening national unity and oneness and fortifying national resilience.

Tradition and historical values need to be maintained and guided in order to cultivate historical awareness, fighting spirit and love of the country along with maintaining the 
preservation of culture and the continuity of development.

The promotion of the national culture under REPELITA $V$ in principle is an effort to create a socio-cultural condition that is in line with the value of the nation's identity that is based on Pancasila (Indonesia, Republic of, 1991: 107-108).

[Page 58]

Journal of World-Systems Research

Pancasila is the government's national ideology, designed to universalize an Indonesian identity. Its five principles--belief in one Almighty God, a just and civilized humanity, the unity of Indonesia, democracy guided by the wisdom of representative deliberation, and social justice for all Indonesians--are the basis of "national development." It is promulgated as a form of control over the diverse regions and cultures of the Indonesian "nation-state." Both Sukarno and Soeharto invoked it in order to attempt to instill in the people of Indonesia a drive for development. It has been, in effect, a tool of development. Recalling what Wallerstein says about culture, "Cultures are precisely arenas where resistance to hegemony occurs, where appeals are made to historical values of established 'civilizations' against the temporary superiorities of the market" (1980:65), Pancasila is a synthetic culture (drawn from ancient tradition) that can be invoked to resist the hegemony of global capitalism by appealing to a national ideal. Under Sukarno, nationalism appeared in an anti-systemic strategy of development in the sense of "nationbuilding" as the remnants of anti-colonial resistance to the core. However, under Socharto, while reference to the "values of the nation's identity" remained, nationalism became a rhetorical tool of economic development in opposition, ironically, to the sort of anti-capitalsit movement of Sukarno, and in support of the widening and deepening of "stateness," as part of the rise of the global transformed historical ground.

Under Soeharto, regional resistance within the Indonesian "nation-state" became an enemy to development. ${ }^{15}$ This is apparent in the regional disparities that I shall examine later. However, it is important to consider again the nature of the "nation-state." Returning to Wallerstein's "transformed historical ground," there was, during Soeharto's New Order, a "widening" and a "deepening" of "stateness." Just as there is an increase in the "relational networks" between states, so there is within them. Wallerstein has also argued that nation-states are "created" by the world-system (1991). ${ }^{16}$ For example, as a colony, India was created by the British, and the Indians themselves constructed their state out of an understanding of their own historicity. Wallerstein's proposition is that any given "nation-state" is the result of its historicity. Similarly, Indonesia can be considered a nation-state because the world-system fostered its creation, first as an effect of colonial domination, and then as an effect of the claims to nationalism of the Indonesian government. More than this, I suggest, the Indonesian nation-state, as a creation of the world-system was, in turn, used to help create the system. The regional, cultural, linguistic, and ethnic divisions that constitute the archipelago explain the attempt to build an Indonesian nation under Soeharto. Whereas Sukarno understood the nation in 
opposition to the global capitalist system, Socharto understood the nation as a product of the world-system of capitalism, as integral to development within that system.

Wallerstein continues: "There is no question that, at the present time, nationalism in general, certainly including India, is a remarkably strong world cultural force. It seems stronger today than any other mode of social expression or collective mentality. . . Nationalism, in historical terms, is a very new concept. It is clearly the product . . .of the modern world-system" (pp.133-34). And, as a product of that system, the success of Indonesian development would need to be measured in te rms that the system prescribes, that is, in terms of "ascent" within the system.

[Page 59]

Journal of World-Systems Research

The Problems of Integration: Indonesia "Ascends"

While the Five Year Development Plans include appeals to nationalist ideology, the plans do not emphasize nationalism. The central concern of devlopment under Soeharto was economic success --"ascent" in the system of global capitalism.

Indonesia's economic "success" during this period has been well-documented. ${ }^{17}$ In 1965 , Indonesia's Gross Domestic Product (GDP) was about $\$ 3.8$ billion; in 1989 it was about $\$ 94$ billion. For Indonesia to ascend, it would need to engage in core-like activities, that is, there would need to be a shift from agricultural to non-agricultural production. The following comparisons show this to be the case. The percentage of GDP in agriculture went down from $56 \%$ in 1965 to $23 \%$ in 1989 , while industrial GDP went up from $13 \%$ in 1965 to $37 \%$ in 1989 . Manufacturing and services also increased as a percentage of GDP. Manufacturing increased from $8 \%$ to $17 \%$; services rose from $31 \%$ to $39 \%$ (World Bank 1991: 208). Furthermore, energy consumption per capita, as an indication of industrialization, increased from 91 to 263 kilograms of oil equivalent between 1965 to 1989 (World Bank 1991: 212). These figures describe an industrializing Indonesia that was poised to ascend in the world-system. As a peripheral nation-state it had signs of having semi-peripheral status.

Despite such evidence (that Indonesia appeared poised for ascent), Indonesia's external national debt increased significantly from around $\$ 20$ billion in 1980 to nearly $\$ 70$ billion in 1990 (World Bank: 1990). The growth in debt is even more striking over the 20 year period beginning in 1970 , when total external debt was only $\$ 2.5$ billion (World Bank 1991: 244). Because the IMF has become the leading referee of "Third World" debt, the effect on Indonesia, through increasing reliance on IMF regulated loans, is that it has become increasingly--in fact, exponentially increasingly--reliant on the IMF. The relationship that began in 1966 mushroomed into one of dependence on the IMF for guidance in dealing with debt. Robison (1986) explains, "While the prospect of being caught in a debt trap as consuming as those of Brazil, Argentina or Mexico is remote, 
Indonesia's reliance on loans makes it increasingly susceptible to pressures from the World Bank for structural adjustment" (p. 381). $\frac{18}{\text { (Of course, the economic collapse }}$ associated with the fall of Soeharto has resulted in tremendous reliance on the IMF, and a resumption of a significant servicing of debt to the institutions of a "transformed historic ground.")

Although the national statistics of growth are impressive, three important points should be considered. First, the Indonesian economy, while growing at high rates, averaging $5.1 \%$ between 1984 and $1991, \stackrel{19}{ }$ was still plagued by the problems associated with its integration into the capitalist global market. Second, although Indonesia ranked ninth on the Human Development Index in terms of a positive change, rising from 0.316 in 1970 to 0.491 in 1990 (World Bank 1990), its overal position remained "low" (as opposed to medium or high), ranking Indonesia at 98th of the world's countries. Third, for all the rhetorical attention (to the extent that it appears) to "regional development" in Repelita II$\mathrm{V}$, there continued to be serious regional economic disparity by the early 1990 's.

The force of development under Socharto was to attempt to effect the building of an Indonesian nation that was to be developed economically--in other words, a nation whose development could be measured in terms understandable in the language of a culture of capitalism. To do this, the strategy of development relied heavily on the institutions and mechanisms of a "transformed historical ground," to use (and, in turn, to be used by) the techniques of development recommended by Western-oriented officials, and provided by an expanded system of banking and financial institutions. In short, Soeharto literally bought into the capitalist world-system, making Indonesia reliant upon it as a culture of development. In this way, the nation he was building was actually being built by the system, becoming, as Wallerstein expresses it (and the choice of words here is telling), a "product of the world-system."

[Page 60]

Journal of World-Systems Research

As such, success of this project would necessarily be in terms prescribed by that system; that is, development was measured primarily in the aggregate terms of national economic development. Under these terms, Socharto was successful in building an economically developed, aggregate "nation." However, in other terms, this sort of nation-building was a failure. Inequity remained a characteristic feature of Socharto's "nation." In the final section, I wish to draw attention to this failure not only to point out inequity, but also to point out that the measurement of success (as was the concept itself of "development") was based in the language of the institutions of the "transformed historical ground" of the capitalist world-system.

Poverty in Indonesia 
By the 1990's, capital derived from the development of Indonesia as a "nation-state" had yet to make its way to a significant portion of Indonesia's people. (By the turn of the century, with the end of the "Asian economic miracle," poverty and hunger became pervasive.) The problem was that capital formation, where it happened, took place at the economic and political centers of Indonesia, leaving the rest of the country outside the system. In effect, Socharto's "nation" was exclusive to the pockets of Indonesia that became integrated into the global capitalist system.

I shall now consider the two most extensive assessments of economic growth and poverty in Indonesia for the years that complete the period (1966-1990) ${ }^{20}$ The first is a report prepared by the World Bank (1990); the second is the work of the Indonesia Project at the Australian National University (Hill 1989). Part of the work of the World Bank is to promote itself by focusing on its success. Association with the culture of capitalism is enhanced when developing states are made to believe in the success of that culture. The effect of the World Bank report is a replication of a myth of success in the face of continuing problems associated with development. It is an interesting case of marketing at the highest altars of capitalism.

According to the World Bank report, Indonesia: Strategy for a Sustained Reduction in Poverty (World Bank 1990), in Indonesia, "The percentage of the population in poverty and the absolute number of the poor declined during the 1980s. Income inequality has also declined during the $1980 \mathrm{~s} "$ (p. 1). There are three important points about the report's findings. First, the report concentrates on aggregate data, making distinctions between urban and rural sectors, but offering only very sketchy regional statistics (see Table 1). In fact, the only finding the report explicitly makes about regional inequity is as follows: "In 1987, the incidence of poverty. . remained substantial in the eastern areas (25\%)" (p. 15). Second, recommendations for dealing with the problem of poverty were foremost aimed at pursuing macroeconomic growth. Third, the source and nature of the data used in this study belie a suspect relationship between Indonesian policy makers and the World Bank.

[Page 61]

Journal of World-Systems Research

TABLE 1

\section{OFFICIAL ESTIMATES OF POVERTY: 1980-87 (WORLD BANK) INCIDENCE OF POVERTY BY AREA ${ }^{\text {a }}$-- 1984-87}

1984

Urban Rural Total Urban Rural Total

$\begin{array}{lllllll}\text { Java and Bali } & 25.0 & 23.6 & 24.0 & 21.0 & 17.8 & 18.8 \\ \text { Outer Islands }^{\text {Western }} & \underline{18.4} & \underline{16.6} & \underline{16.9} & \underline{17.6} & \underline{14.0} & \underline{14.8} \\ \text { Westr }^{14.0} & 9.6 & 10.5 & 13.7 & 8.3 & 9.5\end{array}$




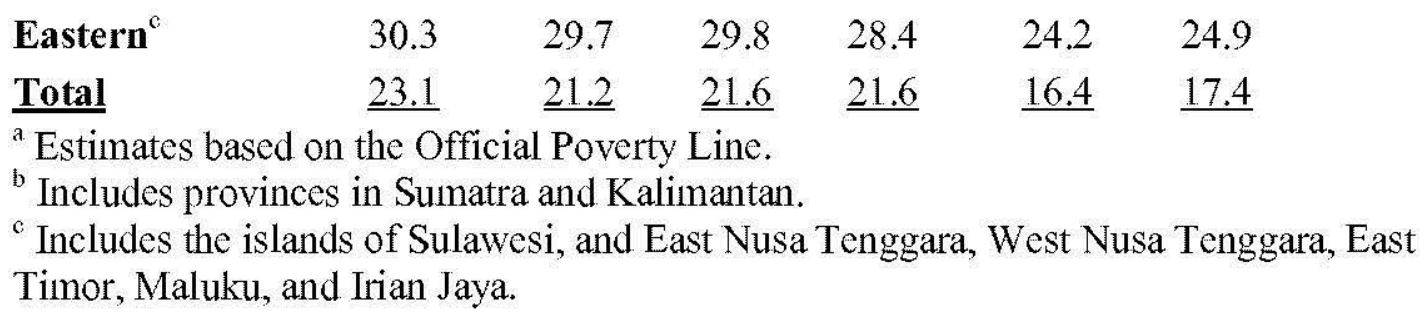

Source: World Bank staff calculations from 1984 and 1987 SUSENAS surveys. Cited in: World Bank (1990:15).

[Page 62]

Journal of World-Systems Research

Winters (1995) reveals a "special relationship" that the World Bank had with Indonesian officials that places in question not only the veracity of such reports, but also the practices of capitalist development.

The problem of counting the poor prompted an illuminating controversy in 1989, when the World Bank was drafting the 1990 World Development Report that would showcase Indonesian development. When the Bank, as is its custom in Indonesia, circulated the report to Indonesian officials for their approval, conflict arose because the Bank used a definition of poverty that yielded a significantly higher number than the 30 million announced publicly by Socharto. This led to several rounds of negotiations between the Bank and Indonesia's ministers to settle on an acceptable number that would not embarrass Suharto, who had apparently picked his number out of thin air. Without even so much as a footnote to alert trusting leaders to these negotiations, the Bank ended up relying completely on Indonesian data and definitions, so that the figure published in the 1990 report was exactly 30 million. (p. 422)

Winters also points out that the government's definition of poverty in Indonesia (upon which the World Bank has relied), even by 1994 , was (equivalent to) $\$ 9.30$ per month for people who lived in rural areas and $\$ 13$ per month in cities, and was "barely enough to buy the cheapest brand of instant noodles three times a day. . . [meaning] that no money [was] left over for shelter, clothing, health expenses, or transport" (p. 422). The measure of ascent was as illusory as ascent itself. In this account, one can read a complicity between the institutions of the "transformed historical ground" and a corrupt cadre of Indonesian officials--officials who were determined to see to it that ascent would be assured by bending the statistics to prove "success." $\underline{21}$

The other work, Unity and Diversity: Regional Economic Development in Indonesia since 1970 (Hill 1989), surveys each region (and considers the further dimension of development in the provinces). The work's editors summarize the findings of these surveys: 
[M]any crucial issues in regional development remain unsolved. They might have remained submerged--as they have for most of the post-independence era--had there not been a dramatic decline in Indonesia's terms of trade in the mid-1980s. Now, however, a financially constrained central government no longer has the capacity to fund major development projects throughout the country. Jakarta must look more to the regions for ideas, money, and initiative. Reforms are required in regional finance, in the delegation of administrative authority, and in national programmes--from rice to trade policy and transmigration--which have a regional impact. The "unity" of the last 20 years of strong central government has to be complemented more effectively by the "diversity" which flows from a greater emphasis on regional initiative and self-reliance (p. 53).

In effect, the recommendations in this report point to an Indonesian nation divided between a purportedly "successful" and integrated Indonesia located in the centers of capitalist economic activity and another Indonesia that remained outside the system and, by any measure, in poverty.

[Page 63]

Journal of World-Systems Research

\section{Conclusion}

In the late 19th and early 20th centuries, the Dutch implemented what was called the "Ethical Policy" in the Dutch East Indies (Saunders 1984). In many ways, this was a precursor to development in postcolonial Indonesia. Whether or not the effect of this policy was in fact "ethical," it contributed to the rise of Indonesian nationalism, which was later to become the foundation for claims to an Indonesian nation-state. The "Ethical Policy" of concerned Dutch colonialists bears a resemblance to the recent apparent concerns of the representatives of the World Bank for development in Indonesia. The resemblance suggests what has been a common characteristic of the world-system: wherever there is capitalism, there also is exploitation and a concern to conceal it.

To summarize, World-System Theory is a plausible framework of explanation of the development strategies of Indonesia during the period of the 1950's through the 1990's. Sukarno's development strategies, moving from a brief period of integration into the world-system early in his rule to dissociation by the late 1950 's, came to be organized according to an understanding of nationalism that drew upon the nationalist period of the colonial period. The meaning of "development" changed under Soeharto to pay homage to the global market, eschewing in practice Sukarno's "nation-building" in favor of economic development. Economic activity during the New Order under Soeharto moved Indonesia towards integration into the system by working within a capitalist cultural orientation, implementing policies commensurate with that orientation. Indonesian development strategies under Soeharto included elements of nationalism in the rhetoric of the plans written by Indonesian policy makers. However, in practice, the rhetoric of national self-reliance took a back seat to economic reliance on the institutions of the 
"transformed historical ground" of the global capitalist system in an attempt to ascend within the system. As a measure of ascent, economic "success" is identifiable only in the centers of Indonesian society where assimilation was most likely to occur. Despite the (questionable) findings of the World Bank, for the rest of society, the effects of assimilation and "ascent" were a perpetuation of economic inequity and poverty. Just as Sukarno's "development" of the Indonesian economy was a dismal failure, Soeharto's economic "nation" was a dismal failure inasmuch as its (relatively few) members were members of a nation built of, by, and for the capitalist world-system, leaving most of society on the side of the road to "ascent." In short, the economic struggle of ascent involved a cultural struggle between capitalism and nationalism, as uneven in its results as in the process.

One cannot assume that the Berkeley Mafia, their descendants, or their benefactors, the IMF and the World Bank, can have all the answers to the social, political, and economic problems of Indonesia. When huge and powerful groups such as these fail --and arguably fail miserably--perhaps it is time to ask the people for whom any system is anathema to making ends meet what ought to be done. The answer could well be as illuminating as any concocted by any of those who, for the past fifty years, have purported to have in mind Indonesia's "development."

[Page 64]

Journal of World-Systems Research

\section{Notes}

1. Wallerstein does not develop this argument to any great extent in the context of Dutch hegemony vis-a-vis the peripheral area of the Dutch East Indies. Dutch colonialism in the Indonesian archipelago flourished a century later. Its effects were devastating on the local economy. According to Kemasang, "Dutch 'mercantilism' destroyed the chances of Indonesia's domestic bourgeoisie and set back its growth for over 200 years" (1985:57). Kemasang shows how the Dutch, specifically the Dutch East India Company (VOC), first gained access to, and then supplanted, the indigenous (priyayi) monopoly in the spice trade by using the Chinese as trading liaisons and later as tax collectors. When the Chinese themselves gained access to capital they became a perceived threat to the Dutch, first as a capitalist class themselves, and then as effecting the revival of an indigenous capitalist class. In 1740, the Dutch slaughtered "around 10,000 Chinese in and around Batavia [now central Jakarta] alone, about $10 \%$ of the region's total population, [and] put an end to any remaining chances that the community ever had of at least catalyzing the growth of a domestic bourgeoisie" (p. 75). These events demonstrate the extent to which a hegemonic power can go to retain ownership of the means of production, and is relevant to the present discussion as an explanation of the historical constraints of 20 th century Indonesian development. See also Kemasang (1982) for an anal ysis of similar effects of colonialism elsewhere in Asia. 
2. Needless to say, what "culture" is has been the issue of considerable debate. Notice that I begin this paragraph with the phrase: "Culture' might be seen. . ." I carefully choose this wording because, if culture is anything, it is certainly a matter of interpretation--of what people make of it. In this case, culture can be seen to be the foundation of either nationalism or capitalism. This division is also apparent in terms of the way culture is used as a tool of political and economic strategy. The analysis that follows also suggests this as an indication of what culture might be. In fact, "culture" runs the gamut of epistemological and ontological meaning as well as economic and political strategy. Wallerstein (1990a) proposes that "[t]he 'culture', that is the idea-system, of this capitalist world-economy is the outcome of our collective historical attempts to come to terms with the contradictions, the ambiguities, the complexities of the socio-political realities of this particular system" (p. 38). He continues by arguing that the dualism between nationalism and capitalism (or, as he puts it, between universalism and racisim/sexism), is synthetic, that "the two ideologies are a symbiotic pair" (p. 42), because the two separate ideologies, to the extent that they can be separated, reinforce one another, and, upon closer inspection, undermine one another. In the end, howe ver, Wallerstein sees anti-systemic opposition to universalism (as it is presently enacted) to be generally futile, to the extent that it buys into the division and replicates the perpetuation of the myth that present vocabularies of change are appopriate to future transformation. This is evident in the failure of both Sukarno and Soeharto, both of whom sought the development of Indonesia in the terms recommended by the system--that is, that an Indonesian identity needed developing, using the model of the modern Western state. See also Boyne (1990) and Wallerstein (1990b). In any case, "culture" is made to be an important factor in Indonesia's dvelopment strategies by the agents of development, which makes it an important issue in understanding the "development" of Indonesia.

\section{See also Cox (1983).}

4. Gramsci's view of ideology is relevant to these elements of Wallerstein's "transformed historical ground" (see note 2), since it is manifested in "institutions and apparatuses" with "collective wills." An important element of this essay is, I believe, to demonstrate how this works: the integration of the "nation-state" of Indonesia into the "collective wills" embodied in the "institutions and apparatuses" of the IMF and the World Bank, and the global division of labor.

[Page 65]

Journal of World-Systems Research

5. Bergeson (1990) makes a similar point:

A state acts and communicates through a diplomatic language independent of the local vernacular, at first Latin and later French, and diplomatic representatives (ambassadors, emmisaries, couriers, etc.) and in earlier centuries through linked dynastic families. The point here is that the presence of these linkages precedes state interactions, and further, 
makes it possible in the first place. From this point of view the international system, in the form of its culture (diplomatic language and systems of representation) does not follow the interaction of states, but makes that possible (p. 76).

6. Kuitenbrouwer (1991) explains that the colonial period was a period of great human suffering. "Between 1873 and 1909, 60-70,000 Achenese and 2,000 members of the colonial army were killed in Acheh; 10,500 members of the colonial army, 25,000 Javanese forced labourers and an unknown number of Achenese died of illness, exhaustion or hunger. Starting with Lombok in 1894, the military actions in other parts of the Outer Regions caused the additional deaths of 10-15,000 local inhabitants and about 500 members of the colonial army" (pp. 367-68). The government of postcolonial Indonesia has itself been quite capable of similar--even more horrific--violence. In 1965, just prior to the installment of the New Order under Suharto, as many as 500,000 Indonesians, due to their alleged ties to Communism or due to their Chinese ethnicity, were killed. And in mid-1970's East Timor 200,000 people lost their lives in their struggle for independence during the invasion and occupation by Soeharto's forces. Since then, there have been numerous massacres, including the killing of thousands of people in Irian Jaya and Aceh, as well as East Timor.

\section{According to Tan $(1967: 30)$ :}

On 5 July 1959, President Sukarno issued a decree which had three important effects: it abruptly ended both the country's Western type of parliamentary democracy and its liberal economy; it dissolved the Indonesian Constituent Assembly installed in 1956 to draft a replacement for the interim Constitution of 1950; finally, it resurrected the original Constitution of 1945 (Undang-Undang Dasar or UUD 1945) as the nation's organic law. Its preamble contained Pantia Sila, the five principles which formed the philosophical basis of independent Indonesia...

A. . source of guidance. . was Manipol-Usdek. . . President Sukarno explained that Manipol-Usdek consisted of five essential elements:

1) The Constitution of 1945 , being the original constitution upon the proclamation of Independence, was the true and proper fundamental law of the state.

2) A consequence of that Constitution was Indonesian socialism.

3) Indonesian socialism entailed guided democracy.

4) Guided democracy in turn entailed guided economy.

5) The whole doctrine embodying these points gave rise to the concept of Indonesian Identity, the moral and intellectual characteristics which informed the Indonesian nation.

Hence came the acronym Usdek which. . was used to name and popularize the fresh exegesis of the philosophy of the state:

U -- Undang-Undang Dasar 1945: the Constitution of 1945

$\mathrm{S}$-- Socialisme a la Indonesia: Indonesian socialism

D -- Demokrasi Terpimpin: Guided democracy

E -- Ekonomi Terpimpin: Guided economy

$\mathrm{K}$-- Kepribadian Indonesia: Indonesian Identity. 
[Page 66]

Joumal of World-Systems Research

8. Moon cites Jones' statement: "American Embassy in Jakarta to U.S. Department of State, Foreign Service Despatch 445, 12/12/60, p. 13, RG 469, O/FE, Indonesian Subject Files, 1953-1961, Box 69, U.S. National Archives, Washington, D.C.

9. Sukarno made this reference in his Presidential Address on the 20th Anniversary of Independence, 17 August 1965: "Reach for the Stars! A Year of Self-Reliance." See Tan $(1967: 22)$.

10. This excerpt is from "The President's Independence Day Address," 17 August 1963, reprinted in Feith and Castles (1970).

11. Liddle (1991) sorts out the economic policy makers of the New Order as being either "nationalists," "patrimonialists," or "economists." Socharto associated himself with the nationalists and patrimonialists to the extent that they supported Socharto's deference to nationalism. However, as Liddle points out, the economists (the group that are identified as being, or being in league with, the "Berkeley Mafia") received Socharto's enduring favor because of the "success" of their liberal economic policies. Liddle also proposes an alternative argument to the one presented here. He entertains several factors that might have contributed to an increase in liberal economic policy in Indonesia, including international economic forces, domestic culture, patrimonialism, and economic crisis. He contends that all of these contributed to the choice of liberal policy, but argues that it was primarily a matter of Soeharto's own "voluntary" and "autonomous" choice. This certainly was an important factor. Socharto's own personal interests were no doubt at stake in the choice of development strategies. However, the question of the agency of a single individual cannot account for the overwhelming power of the forces of nationalism and/or capitalism that made the choices available to him, nor can it account for the multiplicity of historical and structural forces that he faced.

12. On a visit to Sulawesi in 1995 , residents there indicated to me that the issue of free trade in cloves and copra was of great concern to the people who lived there, as the central government was tightening its control on that trade. Because of a continuance of tight controls by the central government, the region was experiencing severe economic hardship--at a time when the center was experiencing sharp economic growth. Similar instances of unequal development were taking place throughout the archipelago.

13. The biographical information which follows on government officials, educators, and so on, were taken primarily from two sources: Roeder, Who's Who in Indonesia (1980); and International Forum Indonesia, International Forum Indonesia (1990). See also National Development Office, Republic of Indonesia (1988); Finch and Lev (1965); and England (1987). 
14. These are also taken from Who's Who in Indonesia, Roeder (1980) and International Forum Indonesia, International Forum Indonesia (1990). The list is only a very brief sample. Positions listed are partial.

[Page 67]

Journal of World-Systems Research

15. One important aspect that relates to development strategies was the emergence in 1989 and 1990 of the idea of openness (in Indonesian, "keterbukaan") (Hein 1990), which came on the heels of the openings in the Soviet Union and Eastern Europe that had been taking place under the rubrics of glasnost and perestroika. Openness in Indonesia suggested a receptiveness to political freedom and economic liberalization. In an Indonesian context, a debate over openness was conducted in terms of a conflict between "Asian values" and globalization. This debate found its way into the debate over development strategies inasmuch as nationalism generall y reflected "Asian values" and liberalization reflected the globalization of capitalism. In short, Socharto embodied the dilemma facing Indonesian society by adhering to "Asian values" in his ongoing efforts to promulgate Pancasila as the guiding principle of the development of Indonesian society, while at the same time continuing to promote macro-economic policies that accepted the infusion of globalization to the extent that it contributed to Indonesian economic development. In fact, this issue was nothing new to Indonesian politics and economics, in which "globalisasi" and "gaya hidup baru moderen" ("new modern life style") had long been the subject of derision among traditionalists in Indonesia. Under Sukarno, this conflict of values included a Marxist criticism of Western capitalist exploitation. Under Soeharto, the conflict lost this ideological attitude, but was essentially quite similar. How the debate over openness in Indonesia in the 1990's has impacted the development strategies that Indonesia will pursue into the next century would require further investigation. However, one might speculate that the openings inspired by keterbukaan eventually led to the violent transition that Indonesia was undergoing at the end of the century.

16. The article "Does India Exist?" was originally a session paper published in "Historical Sociology of India," XI World Congress of Sociology, New Delhi, August 18-23, 1986.

17. See Booth and McCawley (1981); Bunton (1983); Dickie (1988); and Soehoedi (1976) for more on Indonesian economic development since 1966. For reports on the effect of the world market on Indonesia's economy see Friedland (1991); Poot (1990); Robison (1986); Rowley (1987); Schwartz (1991a; 1991b; 1991c); Wertheim (1980); and Winters (1988).

18. See also Robison (1988).

19. According to Asia Service (Wharton Econometrics), Jardine Fleming Nusantara (cited in Far Eastern Economic Review, 18 April 1991, 44.) 
20. Poot (1990) offers the following data: GINI indexes based on Gross Regional Domestic Product per capita, that is, based on the internal economic production of the region are, "unweighted," 0.292 (Java), 0.535 (Outer Islands), 0.519 (Indonesia); and "population weighted," 0.176 (Java), 0.470 (Outer Islands), 0.360 (Indonesia), where a 1.0 would indicate "perfect" income inequality. While Poot goes on to show that the disparities are less significant when accounting for the mining sector, which should be expected, the disparities in these GINI indexes cannot be ignored. Furthermore, when one considers that these are regional statistics, the disparities internal to the "nation-state" of Indonesia would become even more dramatic in relation to the world-system as a whole.

[Page 68]

Journal of World-Systems Research

21. Wallerstein (1990a) argues:

The real sleight of hand is to engage in national rather than global measures... [i]t is perfectly possible for real income, as measured by GNP per capita say, to rise in some countries while going down in others and in the system as a whole. But since the countries in which the rise occurs are also those most extensively studied, observed, and measured, it is easy to understand how facile but false generalizations take root. In addition, despite the better statistical systems of such core countries, it is undoubtedly the case that they do not measure adequately the non-citizen component of the population (often illegally in residence). And since this is the poorest component, the bias is evident" (pp. 48-49).

\section{References}

Arndt, H.W. (1984). The Indonesian Economy: Collected Papers. Singapore: Chapmen Publishers.

Avery, William P. And David P. Rapkin, eds. (1982). America in a Changing World Political Economy. New York: Longman.

Bergeson, Albert (1990) "Turning World-System Theory on Its Head." Theory, Culture \& Society, 7, 67-81.

Booth, A. and McCawley, P., eds. (1981). The Indonesian Economy During the Soeharto Era. Kuala Lumpur: Oxford University Press.

Boyne, Roy (1990) "Culture and the World-System." Theory, Culture \& Society, 7, 57 62.

Bunton, J. (1983). Building Indonesia: A Market Survey. London: Construction Press. 
Chase-Dunn, Christopher (1981). "Interstate System and Capitalist World-Economy: One Logic or Two?" In W. Ladd Hollist and James Rosenau, eds., World-System Structure: Continuity and Change. Beverly Hills: Sage.

(1990). "Resistance to Imperialism: Semiperipheral Actors." Review, 13, 1-

31.

Cox, Robert (1983). "Gramsci, Hegemony and International Relations: An Essay in Method." Millennium, 12, 162-75.

Devan, J. (1987). "The Economic Development of the ASEAN Countries." In P. West and F. A. M. A. Von Guesau, eds., The Pacific Rim and the Western World: Strategic, Economic and Cultural Perspectives. Boulder: Westview Press.

Dickie, R.B. and Layman, T.A. (1988). Foreign Investment and Government Policy in the Third World: Forging Common Interests in Indonesia and Beyond. New York: St. Martin's Press.

Drake, C. (1989). National Integration in Indonesia: Patterns and Policies. Honolulu: University of Hawaii Press.

England, V. (1987). "Who's Who in Jakarta." Far Eastern Economic Review, 10, 72-73.

[Page 69]

Journal of World-Systems Research

Feith, Herbert, and Castles, Lance, eds. (1970). Indonesian Political Thinking: 19451965. Ithaca, New York: Cornell University Press.

Finch, Susan, and Lev, Daniel S. (1965). Republic of Indonesia Cabinets:1945-1965. Ithaca, New York: Southeast Asia Program, Cornell University.

Friedland, J. (1991). Aiming for a World Market. Far Eastern Economic Review, 18, 5051.

Friedman, Jonathan (1989). Culture, Identity, and World Process. Review, 12, 51-69.

Glassburner, Bruce, ed. (1971). The Economy of Indonesia. Ithaca: Cornell University Press.

Goldstein, Joshua (1988). Long Cycles: Prosperity and War in the Modern Age. New Haven: Yale University Press. 
Hein, Gordon R. (1990). "Indonesia in 1990: A Question of Openness." Asian Survey, 30, 2, 221-30.

Heryanto, Ariel (1988). "The Development of 'Development."' Indonesia, 46, 1-24.

Hill, Hal, ed. (1989). Unity and Diversity: Regional Economic Development in Indonesia Since 1970. Singapore: Oxford University Press.

Indonesia, Republic of, Department of Information (1969). The First Five-Year Development Plan: 1969/70-1973/74. Jakarta: Indonesia, Republic of, Department of Information.

Indonesia, Republic of, Department of Information (1980). The Second Five-Year Development Plan: 1974/75-1979/80. Jakarta: Indonesia, Republic of, Department of Information.

Indonesia, Republic of, Department of Information (1979). The Third Five-Year Development Plan: 1979-1984 (Summary). Jakarta: Indonesia, Republic of, Department of Information.

Indonesia, Republic of, Department of Information (1991). The Fifth Five-Year Development Plan: 1990/91-1995/96. Jakarta: Department of Information, Republic of Indonesia.

International Forum Indonesia (1990). International Forum Indonesia Who's Who. Jakarta: International Forum Indonesia.

[Page 70]

Journal of World-Systems Research

Kemasang, A. R. T. (1982). "Technology and Western 'Comination' of Asia: Coming Full Circle?" Asian Profile, 10, 3, 287-302.

(1985). "How Dutch Colonialism Foreclosed a Domestic Bourgeoisie in Java: The 1740 Chinese Massacres Reappraised." Review, 9, 1, 57-80.

Kuitenbrouwer, Maarten (1991). The Netherlands and the Rise of Modern Imperialism: Colonies and Foreign Policy, 1870-1902. New York: Berg Press.

Laclau, Ernesto and Chantall Mouffe (1985). Hegemony and Socialist Strategy: Towards a Radical Democratic Politics. Trans., W. Moore and P. Kammack. London: Verso. 
Liddle, R. William (1991). "The Relative Autonomy of the Third World Politician: Soeharto and Indonesian Economic Development in Comparative Perspective." International Studies Quarterly, 35, 403-427.

Moon, Suzanne M. (1998). "Takeoff or Self-Sufficiency? Ideologies of Development in Indonesia, 1957-1961." Technology and Culture, 39, 2, 187-212.

Papanek, G.F., ed. (1980). The Indonesian Economy. New York: Praeger.

Pitt, M.M. (1991). The Experience of Indonesia, Pakistan and Sri Lanka: Indonesia . Cambridge: Basil Blackwell.

Poot, H., A. Kuyvenhoven, and J. C. Jansen (1990). Industrialization and Trade in Indonesia. Yogyakarta: Gadjah Mada University Press.

Robison, Richard (1986). Indonesia: The Rise of Capital. Canberra: Australian National University Asian Studies Association.

(1988). "Authoritarian States, Capital-Owning Classes, and the Politics of NICs: The Case of Indonesia." World Politics, 41, 52-74.

Roeder, O.G., and M. Mahaddin (1980). Who's Who in Indonesia: Biographies of Prominent Indonesian Personalities in All Fields. Singapore: Gunung Agung.

Rowley, A. (1987). Economic Schizophrenia: Indonesia Struggles with Rival Paths to Progress. Far Eastern Economic Review, 10 September, 70-74.

Saunders, G.E. (1984). The Liberal-Ethical Policy in Indonesia. Kuala Lumpur: Longman Malaysia Sdn. Berhad.

[Page 71]

Journal of World-Systems Research

Schwartz, Adam (1991a). "Growth Strains Superstructure." Far Eastern Economic Review, 18 April, 36-39.

(1991b). "Pause for New Growth." Far Eastern Economic Review, 18 April, $33-34$. (1991c). "Time for a World Role." Far Eastern Economic Review, 18 April, $46-47$.

Simon, Sheldon W. (1969). The Broken Triangle: Peking, Djakarta, and the PKI. Baltimore: Johns Hopkins Press. 
Sochoedi, A.R. (1976). "Domestic Economic Strategies in Indonesia" In Indonesia Seminar: Hamburg, November 22-23, 1976, edited by Institution of Asian Affairs. Hamburg: Institution of Asian Affairs.

Tan, T.K. (1967). Sukarno's Guided Indonesia. Melbourne: Jacaranda Press.

Wallerstein, Immanuel (1974). The Modern World-System I: Capitalist Agriculture and the Origins of the European World-Economy in the Sixteenth Century. New York: Academic Press.

(1980). The Modern World-System II: Mercantilism and the Consolidation of the European World-Economy, 1600-1750. New York: Academic Press.

(1984). "Long Waves as Capitalist Process." Review, 4, 559-76.

(1988). The Modern World-System III: The Second Era of Great Expansion of the Capitalist World-Economy, 1730-1840. New York: Academic Press.

(1990a) "Culture as the Ideological Battleground of the Modern WorldSystem." Theory, Culture \& Society, 7, 31-55.

(1990b) "Culture is the World-System: A Reply to Boyne." Theory, Culture \& Society, 7, 63-65.

(1991). Unthinking Social Science: The Limits of Nineteenth Century Paradigms. Cambridge: Polity Press.

Wallerstein, I., G. Arrighi, and T. Hopkins (1986). "Dilemmas of Antisystemic Movements." Social Research, 53, 185-206.

[Page 72]

Journal of World-Systems Research

Wertheim, W.F. (1980). Betting on the "Elites" or Betting on the Poor?--The Indonesian Case. Brisbane: James Cook University.

Wilkinson, D. (1996). "World-Economic Theories and Problems: Quigley vs Wallerstein vs Central Civilization," Journal of World-Systems Research , 2, 17.

(http:/jwsr.ucr.edu/archive/vol2/v2 nh.php)

Wilson, D. (1989). The Long Journey from Turmoil to Self-Sufficiency. Jakarta: Yayasan Persada Nusantara. 
Winters, Jeffrey (1988). Indonesia: The Rise of Capital: A Review Essay. Indonesia, 45, 109-28.

(1995). "Suharto's Indonesia: Prosperity and Freedom for the Few," Current History 94/596:420-24.

World Bank (1991). World Development Report 1991: The Challenge of Development. Oxford: Oxford University Press, for the World Bank.

(1990). Indonesia: Strategy for a Sustained Reduction in Poverty.

Washington: World Bank.

[Page 73]

Journal of World-Systems Research 